\title{
Differential aluminum tolerance of Portuguese rye populations and North European rye cultivars
}

\author{
Olinda Pinto-Carnide*, Henrique Guedes-Pinto \\ Department of Genetics and Biotechnology, University of Trás-os-Montes and Alto Douro, \\ Ap. 202, 5001 Vila Real Codex, Portugal
}

(Received 7 June 1999; accepted 20 October 1999)

\begin{abstract}
Aluminum toxicity is the main toxic factor limiting crop production in acid soils. The development of cereal varieties adapted to such conditions is a great challenge for plant breeding. Identification and introduction of Al-tolerant genes into breeding material is one way of solving the problem. Rye is considered one of the most tolerant species among cereals, although a great intra- and interspecific variability has been found. Al toxicity is usually expressed by an inhibition of root elongation. Therefore, measuring the root regrowth of plants after exposure to an aluminum solution can give a good indication of a plants behaviour in acid soils. This paper compares the behaviour of Portuguese rye populations and European rye varieties when grown at different aluminum concentrations. The results obtained reveal that Portuguese rye populations are more tolerant than the European cultivars, with most of them being even better than the Al-tolerant cv. Dank. Zlote, used as a tester.
\end{abstract}

\section{Aluminum / rye / tolerance / toxicity / variability}

Résumé - Tolérance différentielle à l'aluminium entre populations portugaises et cultivars de seigle du Nord de l'Europe. La toxicité à l'aluminium est le facteur limitant majeur de la production des cultures en sols acides. L'amélioration des variétés de céréales adaptées à ces conditions est un défi pour la sélection végétale. L'identification et l'introduction des gènes de tolérance à l'aluminium dans le matériel végétal à sélectionner est une des stratégies envisagée. Le seigle est consideré comme une des espèces de céréales les plus tolérantes à l'aluminium. Cependant on observe une grande variabilité intra et interspécifique pour ce caractère. La toxicité à l'aluminium s'exprime généralement par une inhibition de la croissance racinaire. La mesure de la croissance des racines après traitement par une solution nutritive contenant de l'aluminium est bien corrélée avec le comportement des plantes dans les sols acides. Dans ce travail nous avons étudié et comparé le comportement de populations portugaises et celui de cultivars européens de seigle en

Communicated by Nicolás Jouve (Madrid, Spain)

* Correspondence and reprints

ocarnide@utad.pt 
présence de différentes concentrations d'aluminium. Les résultats observés indiquent que les populations portugaises sont plus tolérantes que les cultivars du Nord de l'Europe, la plupart ayant même un comportement meilleur que le cultivar Dank Zlote, témoin de tolérance à l'aluminium.

Aluminium / seigle / tolérance / toxicité / variabilité

\section{Introduction}

Aluminum is soluble at $\mathrm{pH}$ levels below 5.0 and becomes a major problem to plant growth. Although $\mathrm{pH}$ influences the amount of exchangeable aluminum [10,21], it seems not to be the only factor that determines the activity of soluble $\mathrm{Al}$, even at low $\mathrm{pH}[5,8]$. Nevertheless, the evaluation of $\mathrm{pH}$ gives an idea of the aluminum solubility and, therefore, of its toxicity. The initial and most dramatic symptom of Al toxicity is inhibition of root elongation which can occur within a few hours of exposure to $\mathrm{Al}$ [22]. The injured roots are generally stubby and brittle, root tips and lateral roots become thickned, the root system is weak and limited to the upper soil layers and the plants express nutrition stress and become susceptible to drought.

Aluminum tolerance is genetically controlled and differences among species and cultivars within species to aluminum tolerance have been found [3, $6,7]$. Among cereals, rye is one of the most tolerant species, but a great intraspecific variability has been detected $[4,15]$. Genetic variation in rye can be used by plant breeders in the development of Al-tolerant cultivars and this characteristic can also be introduced to others species, namely wheat and triticale [11]. The introduction of genes from wild, tolerant species can be used to enrich the gene pools of crop species [20]. However, it has been shown that the expression of genes controlling tolerance to aluminum from rye tends to be reduced when they are present in a wheat background [7]. Rajaram et al. [18] have reported that triticale germplasm with the full rye genome possesses a better adaptation and yield potential in marginal environments.
In the north region of Portugal there is a great variability of local rye populations which have been cultivated for several centuries. This variability doesn't exist in the European cultivars. Advanced cultivars maintain an outstanding position in the agricultural systems but this has resulted in a dramatic loss of genetic variability. The favourable characteristics of Portuguese regional rye populations [15], namely the adaptation to low fertility and tolerance to acid soils, have justified their maintenance in the regional agricultural system, but are currently under threat.

The objective of this study was to evaluate several European varieties and the Portuguese populations for aluminum tolerance at three aluminum concentrations and to assess variability within each population/cultivar tested.

\section{Materials and methods}

Eleven rye (Secale cereale L.) cultivars, kindly supplied by cooperators of EUCARPIA Winter Rye Trials from northern Europe (Halo, Pluto, Muro, Peros, SCW 48600 - from Germany - and Dank. Zlote, a tolerant tester, Dank. Nowe, Turbo, SMH 285, Motto and LAD 185 - from Poland), and seven cultivated rye populations (Montalegre, Lordelo, Lamego, Malhadas, Vila Pouca, Padrela and Gimonde - from the farmers of northern Portugal) were studied at 30, 40 and $60 \mathrm{ppm}$ aluminum concentrations. The methodology of Moore et al. [14] and Poole et al. [17] with some modifications suggested by Aniol [2], was used. Three replications with about fifty seedlings of each cultivar/population were studied. 
The kernels were sterilized with $0,1 \%$ of $\mathrm{Hg}_{2} \mathrm{Cl}_{2}$ aqueous solution for $10 \mathrm{~min}$, rinsed with tap water and germinated on filter paper in petri dishes. After germination, when the roots reached about $5 \mathrm{~mm}$ in lenght they were placed in the following nutrient solution: $0.4 \mathrm{mM} \mathrm{CaCl}, 0.65 \mathrm{mM} \mathrm{KNO}_{3}, 0.25$ $\mathrm{mM} \mathrm{MgCl} \cdot 6 \mathrm{H}_{2} \mathrm{O}, 0.01 \mathrm{mM}\left(\mathrm{NH}_{4}\right)_{2} \mathrm{SO}_{4}$ and 0.04 $\mathrm{mM} \mathrm{NH} \mathrm{NO}_{3}$. Forty eight hours later, the seedlings were transferred to another nutrient solution containing $\mathrm{Al}$ in the form of $\mathrm{AlCl}^{3} .6 \mathrm{H}^{2} \mathrm{O}$ at 30,40 and $60 \mathrm{ppm}$ aluminum concentrations. After this treatment, during 48 hours, the roots were stained with
Eriochrome cyanine $\mathrm{R}$ for $10 \mathrm{~min}$ and washed with tap water. All the solutions were aerated continuously and adjusted to $\mathrm{pH}$ 4.0.

After treatment the plantlets were transferred to a new nutrient solution without aluminum, for 48 hours, in order to observe the root regrowth which was measured in three roots per plant. The data presented are the average of three replications (about 150 plants per cultivar/population). The statistical analysis was done using Scheffe's probability test. Differences were considered as significant at the $5 \%$ level.

Table I. Mean (s.e.) of root regrowth (mm) of the North European cultivars and Portuguese rye populations at 30, 40 and $60 \mathrm{ppm}$ aluminum concentrations.

\begin{tabular}{|c|c|c|c|c|}
\hline $\begin{array}{l}\text { Cultivars/ } \\
\text { populations }\end{array}$ & $30 \mathrm{ppm}$ & $40 \mathrm{ppm}$ & $60 \mathrm{ppm}$ & Mean \\
\hline \multicolumn{5}{|c|}{ Europ. cultivars } \\
\hline $\begin{array}{l}\text { Dank. Zlote } \\
\text { (tol. tester) }\end{array}$ & $2.65(0.24) b$ & $1.31(0.18) \mathrm{def}$ & $0.00(0.00) \mathrm{b}$ & 1.32 \\
\hline Pluto & $0.98(0.17) \mathrm{bcd}$ & $0.98(0.11) \mathrm{ef}$ & $0.09(0.02) \mathrm{b}$ & 0.74 \\
\hline SCW 48600 & 1.58 (0.19)bcd & $1.82(0.23) \mathrm{cdef}$ & $0.16(0.03) \mathrm{ab}$ & 1.27 \\
\hline SMH 285 & $0.64(0.08) \mathrm{d}$ & $1.09(0.12) \mathrm{def}$ & $0.06(0.01) \mathrm{b}$ & 0.66 \\
\hline Turbo M6 & $0.98(0.14) \mathrm{bcd}$ & $0.94(0.12) \mathrm{f}$ & $0.04(0.01) \mathrm{b}$ & 0.71 \\
\hline Peros & $0.74(0.07) \mathrm{cd}$ & $1.06(0.19) \mathrm{def}$ & $0.07(0.01) \mathrm{b}$ & 0.68 \\
\hline Lad 185 & $1.25(0.14) \mathrm{bcd}$ & $1.26(0.13) \mathrm{def}$ & $0.61(0.02) \mathrm{a}$ & 1.07 \\
\hline D. Nowe & $0.76(0.13) \mathrm{cd}$ & $0.76(0.11) \mathrm{f}$ & $0.06(0.01) \mathrm{b}$ & 0.57 \\
\hline Motto & $0.87(0.14) \mathrm{bcd}$ & $0.96(0.11) \mathrm{ef}$ & $0.06(0.02) \mathrm{b}$ & 0.76 \\
\hline Muro & $1.30(0.13) \mathrm{bcd}$ & $1.58(0.15) \mathrm{def}$ & $0.12(0.02) \mathrm{b}$ & 1.10 \\
\hline Halo & $1.18(0.17) \mathrm{bcd}$ & 1.11 (0.14)def & $0.12(0.03) \mathrm{b}$ & 0.87 \\
\hline Mean & $1.16(0.04)$ & $1.15(0.04)$ & $0.12(0.02)$ & \\
\hline \multicolumn{5}{|c|}{ Reg. Port. popul. } \\
\hline Montalegre & $4.68(0.40) a$ & $4.45(0.41) a$ & 0.27 (0.09)ab & 2.92 \\
\hline Lordelo & $5.05(0.38) \mathrm{a}$ & $3.24(0.28) a b c$ & $0.00(0.00) \mathrm{b}$ & 2.83 \\
\hline Lamego & $6.28(0.45) \mathrm{a}$ & $4.10(0.41) b c$ & $0.23(0.07) \mathrm{ab}$ & 3.40 \\
\hline Malhadas & $2.51(0.27) b c$ & $1.24(0.18) \mathrm{def}$ & $0.00(0.00) \mathrm{b}$ & 1.21 \\
\hline Vila Pouca & $5.25(0.46) \mathrm{a}$ & $2.54(0.25)$ bcde & $0.07(0.03) \mathrm{b}$ & 2.50 \\
\hline Padrela & $5.85(0.47) \mathrm{a}$ & $2.66(0.28) \mathrm{bcd}$ & $0.10(0.04) \mathrm{b}$ & 2.59 \\
\hline Gimonde & $2.09(0.25) \mathrm{bcd}$ & 1.45 (0.17)def & $0.01(0.01) \mathrm{b}$ & 1.15 \\
\hline Mean & $4.52(0.15)$ & $2.84(0.12)$ & $0.10(0.02)$ & \\
\hline Total mean & $2.36(0.07)$ & $1.79(0.05)$ & $0.12(0.01)$ & \\
\hline
\end{tabular}

\footnotetext{
* Within a column, means followed by the same letter do not differ significantly at $\mathrm{P}=0.05$.
} 


\section{Results}

Root regrowth of the northern European cultivars and Portuguese rye populations at 30, 40 and $60 \mathrm{ppm} \mathrm{Al}$ concentrations are presented in Table I. When the aluminum concentration increases the average values of root regrowth decreased. The average values were $2.36,1.79$ and $0.12 \mathrm{~mm}$ for root regrowth at 30,40 and $60 \mathrm{ppm} \mathrm{Al}$ concentrations, respectively.

On average, over the three aluminum concentrations, the Lamego population attained the highest root regrowth with $3.40 \mathrm{~mm}$, followed by four other Portuguese rye populations: Montalegre, Lordelo, Padrela and Vila Pouca. At 30 and $40 \mathrm{ppm}$ Al concentrations the first position was obtained, respectively, by Lamego and Montalegre populations with 6.28 and $4.45 \mathrm{~mm}$. At the highest aluminum concentration, the root regrowth was practically inhibited reaching, on average, only $0.12 \mathrm{~mm}$.

On average of the European cultivars at 30 and 40 ppm Al concentrations, the behaviour was similar, reaching 1.16 and $1.15 \mathrm{~mm}$ of root regrowth, respectively, which was less than half that reached by the Portuguese rye populations. When considering the three Al concentrations, SCW 48600 was revealed to be the most tolerant European cultivar with $1.27 \mathrm{~mm}$ of root regrowth, and had similar values to Dank. Zlote, a tolerant tester. That cultivar reached the first position at 30 and $40 \mathrm{ppm}$ and achieved one of the highest values at $60 \mathrm{ppm} \mathrm{Al}$ concentration.

A great variability within cultivars/populations was observed (Fig. 1). With the increase of Al concentration the number of plants without root regrowth also increased. The distribution of the plants by different classes of root regrowth at 30 and $40 \mathrm{ppm}$ Al concentrations, shows that the Portuguese regional rye populations registered a higher frequency of plants in the classes with root regrowth greater than $5 \mathrm{~mm}$, in comparison with the European cultivars. At $30 \mathrm{ppm} \mathrm{Al,} \mathrm{all} \mathrm{the}$ plants of the Montalegre population showed root regrowth and the Lamego population also regis- tered a very high number of plants with root regrowth $(99.2 \%)$. No plant with root regrowth greater than $10 \mathrm{~mm}$ was observed at $60 \mathrm{ppm} \mathrm{Al}$ for either cultivars or populations.

Considering the European cultivars, SCW 48600 registered the highest number of plants with root regrowth between $5 \mathrm{~mm}$ and $10 \mathrm{~mm}$ at 30 and 40 ppm Al concentrations. Lad 185 was the only cultivar showing root regrowth higher than $5 \mathrm{~mm}$ at $60 \mathrm{ppm}$ Al concentration.

\section{Discussion}

As expected there is a clear negative effect of the Al concentration on root regrowth with differences between concentrations being statistically significant $(\mathrm{P}<0.001)$. In each of the three treatments, statistically significant differences between cultivars were observed $(\mathrm{P}<0.001)$. However, between replications, the differences were not statistically significant $(\mathrm{P}>0.05)$.

At 30 and 40 ppm Al, variability was observed among the ryes studied. At the highest $\mathrm{Al}$ concentration $(60 \mathrm{ppm})$ there was an almost total inhibition of root regrowth. The European cultivars showed a similar behaviour at 30 and $40 \mathrm{ppm} \mathrm{Al}$ $(\mathrm{P}>0.05)$ while the regional rye populations demonstrated different results in each treatment with the root regrowth values decreasing with $\mathrm{Al}$ concentration. Differences between concentrations were statistically significant $(\mathrm{P}<0.001)$ among the Portuguese rye populations.

The Al-tolerance of the two rye groups (northern European cultivars and Portuguese populations) was very different. Portuguese rye populations were revealed to be more tolerant than the European cultivars at 30 and 40 ppm Al concentrations, the differences being statistically significant $(\mathrm{P}<0.001)$. The values registered for Malhadas and Gimonde, the two populations with the smallest root regrowth, were at the same level, or slightly lower, and not statistically different from Dank. Zlote, which is considered to be a tolerant cultivar. At the highest $\mathrm{Al}$ concentration $(60 \mathrm{ppm})$, the two 

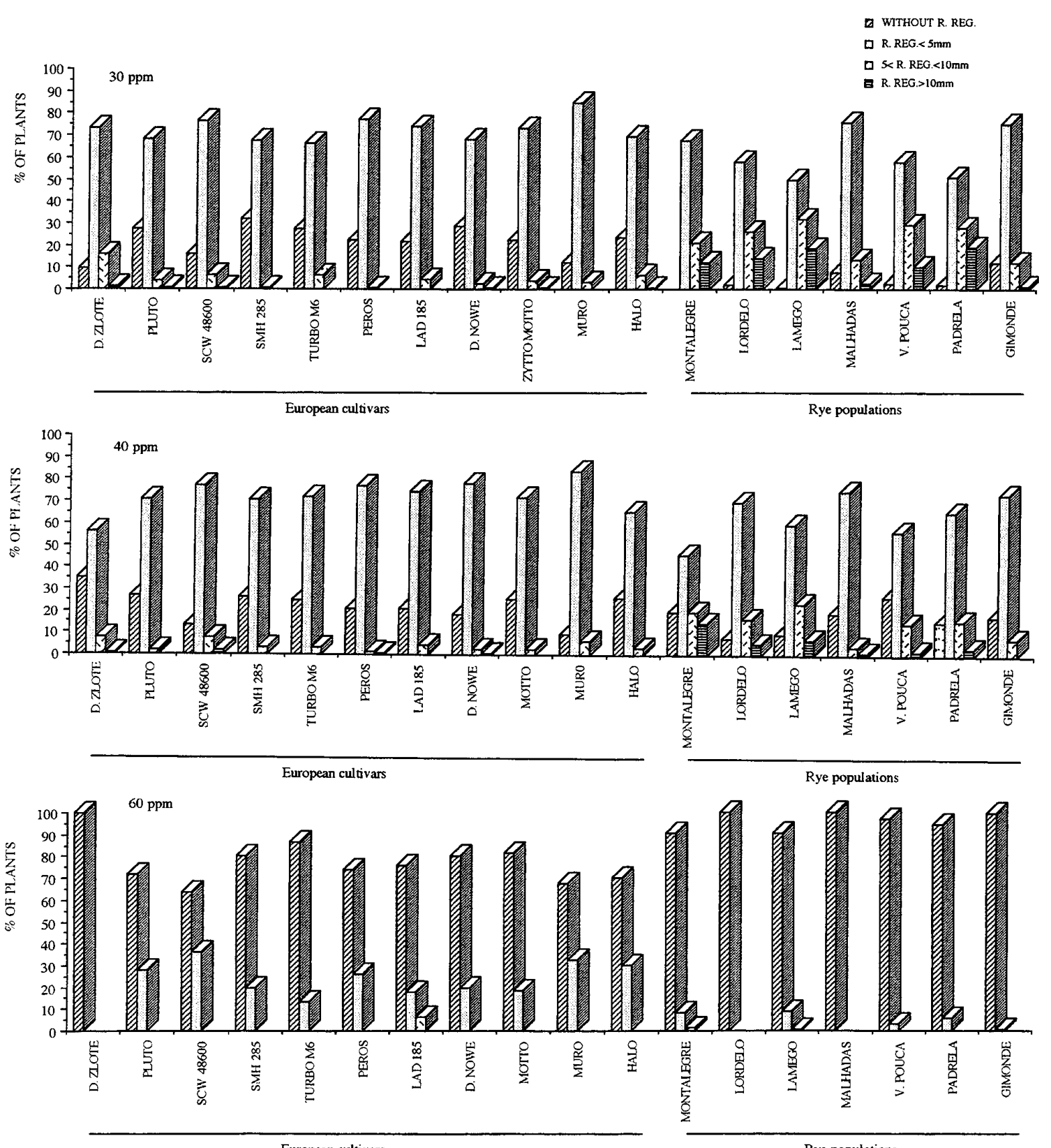

Figure 1. Distribution of the plants by different classes of root regrowth at 30,40 and $60 \mathrm{ppm}$ of A1 concentrations. 
groups revealed the same behaviour with the differences not statistically significant $(\mathrm{P}>0.05)$.

The differential behaviour between the Portuguese rye populations can be explained by an evolutionary process of adaptation to the local conditions. Soil acidity is common in Portugal; some authors claim that $80 \%$ of soils in Portugal are acid $[1,13]$. It is likely that in such conditions plants have been selected for Al-tolerance. This is in accordance with the idea that natural selection favoured genotypes or landraces better adapted to biotic or abiotic stress [12]. An old Portuguese regional landrace of wheat Barbela is also very tolerant to aluminum toxicity, which can also be explained by the action of selection pressure in acid soils.

Generally, aluminum tolerance seems to be limited within a crop species, probably because most cultivated crop species have been selected in favourable, non-stress environments where abiotic stress tolerance traits, if any, would have been gradually lost from gene pools [19].

It should be pointed out that about $40 \%$ of the world's cultivated lands and up to $70 \%$ of the potentially arable lands are acid [9]. In the last decades, the screening for aluminum tolerance genotypes has become a major objective of plant breeding. Nutrient solution screening for aluminum tolerance proved to be an efficient methodology in triticale segregating populations [16]. Our data showed a remarkable aluminum tolerance of most of the Portuguese rye germplasm, showing Al tolerance at 30 and $40 \mathrm{ppm}$, and at least twice the root regrowth average of the tolerant tester, Dank. Zlote.

This germplasm is of great importance for rye breeding, for a potential source of genes for introgression to wheat or inclusion to triticale and for Al tolerance. The great variability found within each rye population, also makes clear the great importance of the collection and conservation of this threatened genetic resource.

Acknowledgements: This work was supported by PTP/AMICA Project. We thanks to Dr. Andrzej Aniol for his critical reading of the manuscript and usefull comments.

\section{References}

[1] Almeida L.A.V., A matéria orgânica e a calagem na fertilização da terra, Bol. Ord. Eng. 4 (1955) 1-16.

[2] Aniol A., Induction of aluminum tolerance in wheat by low doses of aluminum in nutrient solution, Plant Physiol. 75 (1984) 551-555.

[3] Aniol A., Genetics of tolerance to aluminium in wheat (Triticum aestivum L. Thell), Plant and Soil 123 (1990) 223-227.

[4] Aniol A., Hill R.D., Larter E.N., Aluminum tolerance of spring rye inbred lines, Crop Sci. 20 (1990) 205-208.

[5] Coutinho J.F., Acidez do solo e toxicidade do alumínio. Calibração de métodos de avaliação da necessidade em cal, Tese de Doutoramento, UTAD, Vila Real, 1989, p. 709.

[6] Foy C.D., Plant adaptation to acid, aluminiumtoxic soils, Commun. Soil Sci. Plant Anal. 19 (1988) 959-987.

[7] Gustafson J.P., Ross K., Control of alien gene expression for aluminum tolerance in wheat, Genome 33 (1990) 9-12.

[8] Hardgrove W.L., Thomas G.W., Effect of organic matter of exchangeable aluminum and plant growth in acid soils, in: Dowdy R.W. (Ed.), Chemistry in the Soil Environment. Spec. Publ., ASA, Madison 40 (1981) 151-166

[9] Haug A., Molecular aspects of aluminium toxicity, Crit. Rev. Plant Sci. 1 (1984) 345-373.

[10] Hoyt P.B., Effects of organic matter content on exchangeable $\mathrm{Al}$ on $\mathrm{pH}$ dependent acidity of very acid soils, Can. J. Soil Sci. 57 (1977) 221-222.

[11] Manyowa N.M., Miller T.E., Forster B.P., Alien species as sources for aluminium tolerance genes for wheat, Triticum aestivum, Proc. Seventh Int. Wheat Genetics Symp., Cambridge, Vol. II, 1988, pp. 851-857.

[12] Marchenay P., Lagarde M.F., A la recherche des varietés locales de plantes cultivées, Bureau des Ressources Génétiques, Paris, 1987, p. 211.

[13] Martins A.A., Coutinho J.F., Principais características físicas e químicas dos solos de Trás-os-Montes e Alto Douro relacionadas com a sua fertilidade. 1Dados preliminares, Anais UTAD 1 (1988) 205-224.

[14] Moore D.P., Kronstad W.E., Metzger R.J., Screening wheat for aluminum tolerance, in: Plant adap- 
tation to mineral stress in problem soils, Cornell Univ. Press, Itaca, New York, 1976.

[15] Pinto-Carnide O., Guedes-Pinto H., Garcia J., Aluminum tolerance behaviour of Portuguese rye populations, Vortrage für Pflanzenzuchtung 15 (1989) 5-6.

[16] Pinto-Carnide O., Guedes-Pinto H., Vaz E., Aluminum tolerance behavior of F2 6x-triticales and their progenitors, CIMMYT, Proceedings of the Second International Triticale Symposium Mexico, D.F., 1991, pp. 268-273.

[17] Poole E., Konzak C.F., Kittrick J.A., Visual detection of aluminum tolerance levels in wheat by hematoxylin staining of seedling roots, Crop Sci. 18 (1978) 823-827.

[18] Rajaram S., Varughese G., Abdalla O., Pfeiffer W.H., van Ginkel M., Accomplishments and challenges in wheat and triticale breeding at CIMMYT, Plant Breed. Abstr. 63 (1993) 131-139.

[19] Subbarao G.V., Johansen C., Jana M.K., Kumar Rao, J.V.D.K., Comparative salinity responses among Pigeonpea genotypes and their wild relatives, Crop Sci. 31 (1991) 415-418.

[20] Tal M., Genetics of salt tolerance in higher plants: Theoretical and practical considerations, Plant and Soil 89 (1985) 199-226.

[21] Thomas G.W., The relationship between organic matter content and exchangeable aluminum in acid soil, Soil Sci. Soc. Am. Proc. 35 (1975) 591.

[22] Wallace S.V., Anderson I.C., Aluminum toxicity and DNA synthesis in wheat roots, Agron. J. 76 (1984) $5-8$. 